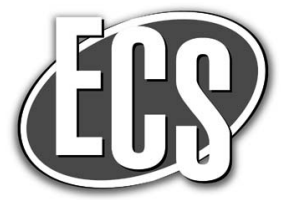

\title{
The Contamination Mechanism and Behavior of Amide Bond Containing Organic Contaminant on PEMFC
}

\author{
Hyun-Seok Cho, ${ }^{\mathrm{a}, *, \mathrm{z}}$ Mayukhee Das, ${ }^{\mathrm{a}}$ Heli Wang, ${ }^{\mathrm{b}}$ Huyen N. Dinh,, ${ }^{\mathrm{b}, *}$ and J. W. Van Zee ${ }^{\mathrm{c}, *}$ \\ ${ }^{a}$ Department of Chemical Engineering, University of South Carolina, Columbia, South Carolina 29208, USA \\ ${ }^{b}$ Chemical and Materials Science Center, National Renewable Energy Laboratory, Golden, Colorado 80401, USA \\ ${ }^{c}$ Department of Chemical and Biological Engineering, University of Alabama, Tuscaloosa, Alabama 35487, USA
}

\begin{abstract}
This paper presents a study of the effects of an organic contaminant containing an amide bond (-CONH-), $\varepsilon$-caprolactam, on polymer electrolyte membrane fuel cells (PEMFCs). The $\varepsilon$-caprolactam has been detected in leachates from polyphthalamide materials that are being considered for use as balance-of-plant structural materials for PEMFCs. Contamination effects from $\varepsilon$-caprolactam in Nafion membranes are shown to be controlled by temperature. A possible explanation of the temperature effect is the endothermic ring-opening reaction of the amide bond (-NHCO-) of the cyclic $\varepsilon$-caprolactam. UV-vis and ATR-IR spectroscopy studies confirmed the presence of open ring structure of $\varepsilon$-caprolactam in membranes. The ECSA and kinetic current for the ORR of the Pt/C catalyst were also investigated and were observed to decrease upon contamination by the $\varepsilon$-caprolactam. By comparison of the CVs of ammonia and acetic acid, we confirmed the adsorption of carboxylic acid (-COOH) or carboxylate anion (-COO-) onto the surface of the Pt. Finally, a comparison of in situ voltage losses at $80^{\circ} \mathrm{C}$ and $50^{\circ} \mathrm{C}$ also revealed temperature effects, especially in the membrane, as a result of the dramatic increase in the HFR.

(C) The Author(s) 2015. Published by ECS. This is an open access article distributed under the terms of the Creative Commons Attribution Non-Commercial No Derivatives 4.0 License (CC BY-NC-ND, http://creativecommons.org/licenses/by-nc-nd/4.0/), which permits non-commercial reuse, distribution, and reproduction in any medium, provided the original work is not changed in any way and is properly cited. For permission for commercial reuse, please email: oa@electrochem.org. [DOI: 10.1149/2.0631504jes] All rights reserved.
\end{abstract}

Manuscript submitted December 29, 2014; revised manuscript received January 22, 2015. Published February 3, 2015. This was Paper 1137 presented at the Boston, Massachusetts, Meeting of the Society, October 9-14, 2011.

Although research efforts have been made to reduce system costs and improve efficiency of polymer electrolyte membrane fuel cells (PEMFCs), cost and durability issues continue to delay their commercialization. ${ }^{1}$ In addition, because contamination of the stack can affect performance and durability, studies designed to elucidate these effects and mechanisms have been receiving more attention. ${ }^{1-41}$

In general, three fundamental contamination mechanisms are known: conductivity loss by ion exchange in the membrane/ionomer, $\mathrm{Pt}$ contamination by adsorption, and water/mass transport issues induced by changes in the gas diffusion layer (GDL) properties. Alkali, alkaline-earth, or transitional-metal cations such as $\mathrm{Li}^{+}, \mathrm{Na}^{+}, \mathrm{K}^{+}$, $\mathrm{Cs}^{+}, \mathrm{Ni}^{2+}, \mathrm{Cu}^{2+}, \mathrm{Ca}^{2+}$, and $\mathrm{Fe}^{3+}$ are well known contaminants that undergo ion exchange $\mathrm{e}^{2-4,6-7,12-30}$ with the proton exchange membrane (PEM) in a PEMFC. Changes in the oxygen reduction reaction (ORR) kinetics at a Pt electrode covered with a Nafion ionomer ${ }^{20-24}$ have also been reported. In addition to the decrease in PEM conductivity due to the reaction with cationic contaminants, a structural change also occurs in the ionomer. This structural change appears to be related to the degradation of $\mathrm{Pt} / \mathrm{C}$ catalyst activity. Catalyst contamination by an adsorption mechanism from feed-gas contaminants such as $\mathrm{SO}_{2},{ }^{8-9}$ $\mathrm{CO},{ }^{10}$ and $\mathrm{H}_{2} \mathrm{~S}^{11}$ are well known. In addition, we have reported that aniline adsorbs onto the $\mathrm{Pt} / \mathrm{C}$ electrode because it contains an aromatic ring and a nitrogen atom in the form of an amine group. ${ }^{31,35}$

In a recent cost analysis, ${ }^{36,37}$ the need for cost reduction of balanceof-plant (BOP) materials increased relative to the need for cost reduction of the stack in PEMFCs. Using off-the-shelf materials for BOP rather than customized hand-made materials may provide an advantage in cost reduction; however, durability may be adversely affected by the contaminants arising from such materials. A few studies ${ }^{37,38}$ have presented evaluation methods for screening plastic materials and have investigated the impacts of such materials on PEMFCs with leachate solutions. Macomber et al. ${ }^{39,40}$ have analyzed the leachate solutions from polyphthalamide (PPA) materials and have identified, via gas chromatography-mass spectrometry (GC-MS) analysis, $\varepsilon$-caprolactam and 1,8-diazacyclotetradecane-2,7-dione (DCDD) as the major chemical species. Their chemical structures are shown in Figure 1. Note that DCDD is a cyclic dimer of $\varepsilon$-caprolactam.
In the present study, we chose $\varepsilon$-caprolactam as a model compound to gain a fundamental understanding of contamination mechanisms of a functional group (i.e., the cyclic amide bond). This knowledge can also aid in understanding the effect of PPA materials and provide guidance in the selection of BOP component materials. A comparison of $\varepsilon$-caprolactam with well-known contaminants ${ }^{1-23}$ and other $\mathrm{N}-\mathrm{H}$-containing contaminants ${ }^{24-35}$ may allow a correlation to be established between functional groups, mechanisms, and in situ PEMFC responses. For example, the hydrolysis of the amine groups of ammonia and aniline ${ }^{24-35}$ under acidic conditions led to substantial conductivity losses in a PEM via ion exchange. We, therefore, speculate a similar contamination mechanism for the $\varepsilon$-caprolactam in the PEM.

\section{Experimental}

Membrane isotherms. - Several mixtures of hydrochloric acid $(5 \mathrm{mN})$ and $\varepsilon$-caprolactam $(5 \mathrm{mN})$ solutions were prepared with different molar ratios for the measurement of the absorption isotherm of a Nafion 115 membrane $(\mathrm{N} 115)\left(3.0 \times 3.0 \mathrm{~cm}^{2}\right)$ at ambient temperature and $90^{\circ} \mathrm{C}$. The $\mathrm{pH}$ values of all the mixtures were adjusted to less than 5 ; thus, the amine group of $\varepsilon$-caprolactam was expected to be hydrolyzed (i.e., protonated) because its $\mathrm{pK}_{\mathrm{a}}$ is close to $9 .{ }^{42}$ Two samples of each solution were prepared to verify reproducibility.

The isotherm experiments included a pretreatment of the membrane, followed by immersion of the membrane in the $\varepsilon$ caprolactam solution of interest and, finally, extraction of the ions. The pretreatment procedure involved one piece of a dry N115 $\left(3.0 \times 3.0 \mathrm{~cm}^{2}\right)$ membrane that was weighed prior to the pretreatment to allow calculation of the ion exchange capacity (IEC); the membrane specimen was then boiled in $2 \mathrm{M} \mathrm{H}_{2} \mathrm{SO}_{4}$ for $1 \mathrm{~h}$ and subsequently stored in deionized (DI) water of $18.2 \mathrm{M} \Omega-\mathrm{cm}$ resistivity (Thermo Scientific Inc., Barnstead Smart2Pure UV, Waltham, MA, USA). The pretreated samples were immersed in each of the mixtures under magnetic stirring for $24 \mathrm{~h}$ to allow equilibration of the reaction (or absorption) between the $\varepsilon$-caprolactam ions and the proton form of the membrane. The solution concentrations before and after the immersion were measured by UV-vis spectrophotometric analysis, as discussed below.

The concentration of the $\varepsilon$-caprolactam species was measured using an ultraviolet-visible (UV-vis) spectrophotometer (Shimadzu UV2101); the absorbance of the samples was measured in 
(a)
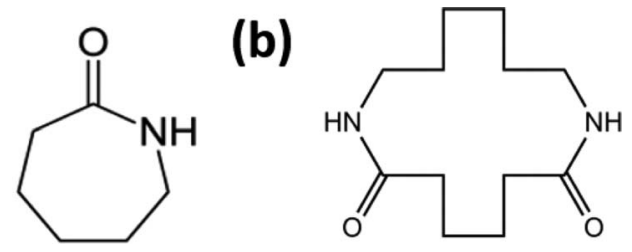

Figure 1. Chemical structures of (a) $\varepsilon$-caprolactam and (b) 1,8-diaza cyclotetradecane-2,7-dione (DCDD).

the wavelength range of 190-400 $\mathrm{nm}$. For the UV-vis analysis, a wavelength of $215 \mathrm{~nm}$ was chosen for quantification of the $\varepsilon$-caprolactam ions in acidic solutions. The calibration curve of the intensity at $215 \mathrm{~nm}$ as a function of the concentration of $\varepsilon$-caprolactam solutions was linear in the concentration range of 0.06 to $5 \mathrm{mM}$, with an accuracy of $\mathrm{R}^{2}=0.9968$. ACS reagent-grade $\mathrm{HCl}, \mathrm{H}_{2} \mathrm{SO}_{4}, \mathrm{NaCl}$, $\mathrm{CaCl}_{2}$, and $\mathrm{NH}_{4} \mathrm{Cl}$ were used as received.

Membrane conductivity measurements.- For the conductivity measurements, a thin Nafion 211 membrane (NRE211) was used to minimize the time required to reach equilibrium. Membrane conductivities for pristine and $\varepsilon$-caprolactam-exchanged NRE211 membranes were determined at different relative humidity (RH) (i.e., 10, 20, 30, $40,50,60,70,80,90$, and $95 \%$ ) by applying DC currents at a cell temperature of $80^{\circ} \mathrm{C}$. A potentiostat (model PAR273) with a four-probe conductivity BT-112 Teflon-based cell (Beckktech LLC) was utilized for the measurements. The cell was equilibrated with a $300 \mathrm{sccm}$ flow of $\mathrm{N}_{2}$ at $80^{\circ} \mathrm{C}$ and $90 \% \mathrm{RH}$ for $1 \mathrm{~h}$ using a Scribner $890 \mathrm{E}$ test station that was calibrated for both flow and humidity. The RH was increased from $20 \%$ to $95 \%$, and the membrane conductivity was measured with a hold time of $1 \mathrm{~h}$ at each $\mathrm{RH}$ to assure equilibrium conditions. Three cycles from low to high RH were performed to assess the reproducibility. A VAISALA dew-point chamber was attached at the outlet of the conductivity cell to confirm the dew-point temperature of the outlet gases relative to those set by the test station. No conductivity changes were observed over three cycles of RH change; we therefore concluded that the exchange percentage did not change during the conductivity measurements.

ATR-IR analyses.- We prepared fresh samples of $\varepsilon$-caprolactamexchanged membranes, $\mathrm{N} 115\left(3.0 \times 3.0 \mathrm{~cm}^{2}\right)$ by soaking the membrane in a mixture of $5 \mathrm{mN} \varepsilon$-caprolactam and $10 \mathrm{mN} \mathrm{H}_{2} \mathrm{SO}_{4}(1: 2)$. The percent exchange of the proton sites was approximately $30 \%$ of the IEC on the basis of the previously described isotherm experiments. The sample was rinsed with DI water to remove any residue and then dried with a nitrogen gas purge at room temperature for 30 minutes. The attenuated total reflectance-Infrared spectroscopy (ATR-IR) spectra were collected on a spectrometer (Nicolet 670) equipped with a detector (Spectratech). The average number of scans per spectrum was 100. Each spectrum was recorded from 4000 to $800 \mathrm{~cm}^{-1}$. We also investigated the solutions of $\varepsilon$-caprolactam and $\varepsilon$-caproic acid extracted from the N115 membranes using $99.8 \mathrm{wt} \%$ methanol to observe any change in the peaks related to the chemical structure of Nafion. The $\varepsilon$-caprolactam and $\varepsilon$-caproic acid spectra in methanol were also compared as references.

Water uptake measurement.- With the objective of comparing water uptake for Nafion membrane, three pieces of NRE212 and N117 $(0.9 \times 4.25 \mathrm{~cm})$ were placed as a sandwich in the Beckktech cell. The cell is equilibrated with a $300 \mathrm{sccm}$ flow of $\mathrm{H}_{2}$ at various temperatures $\left(30,50,80,90^{\circ} \mathrm{C}\right)$ and $90 \% \mathrm{RH}$ for $1 \mathrm{~h}$ using a Scribner 890E PEMFC test station. The humidity was changed from low (20\%) RH to high $(95 \%) \mathrm{RH}$. After hold of $2 \mathrm{~h}$ for each $\mathrm{RH}$ to assure equilibrium conditions, we disassembled the cell, weighed the 3 piece sandwich, and calculated the mass of water uptake.
RDE measurements. - Carbon (Vulcan XC-72R)-supported $45.5 \mathrm{wt} \% \mathrm{Pt}$ (Tanaka, Pt loading $0.02 \mathrm{mg} / \mathrm{cm}^{2}$ ) was dispersed in isopropyl alcohol (IPA) and DI water in the presence of $20 \mathrm{wt} \%$ Nafion ionomer (vs. Pt). The Pt catalyst ink was mixed and ultrasonically dispersed for approximately 20 minutes before being dropped onto a glassy carbon ring disk electrode $\left(0.2475 \mathrm{~cm}^{2}\right)$. This $\mathrm{Pt} / \mathrm{C}$ electrode on glassy carbon is the working electrode whereas a mesh attached $\mathrm{Pt}$ wire was used as a counter electrode. The electrochemical analysis was performed using a PAR model $263 \mathrm{~A}$ potentiostat and a mercury sulfate electrode as the reference electrode; $0.1 \mathrm{M}$ perchloric acid solution $\left(\mathrm{HClO}_{4}\right)$ was used as the electrolyte. All of the potentials are referenced to the reversible hydrogen electrode (RHE) unless otherwise stated. For the high-temperature $\left(73^{\circ} \mathrm{C}\right)$ rotating disk electrode (RDE) experiment, a heating jacket was wrapped around a 3-neck flask that included the $\mathrm{HClO}_{4}$ electrolyte solution and a special RDE tip suitable for high temperatures (Pine Instrument). The electrolyte was purged with pure nitrogen for a minimum of 30 minutes before (and during) the experiments. The electrode was initially subjected to a cleaning procedure that entailed 100 cycles from 0 to $1.2 \mathrm{~V}$ at a scan rate of $100 \mathrm{mV} / \mathrm{s}$ and a rotation rate of $2500 \mathrm{rpm}$. Additionally, while the $\varepsilon$-caprolactam was being injected into the electrolyte, the potential of the WE was maintained at $0.4 \mathrm{~V}$ at $2500 \mathrm{rpm}$ to avoid oxidation of organic compounds at higher potentials. For ammonia-gas-infusion RDE experiments, $997 \mathrm{ppm}$ of ammonia gas balanced in $\mathrm{N}_{2}$ was introduced to the electrolyte through a mass flow controller (MFC). Additional details of the calculation of the amount of ammonia fed to the system are presented in Appendix A.

In situ single-cell tests. - Membrane electrode assemblies (MEAs, $50 \mathrm{~cm}^{2}$ ) provided by GM were used for a single-cell infusion test at different cell temperatures $\left(50^{\circ} \mathrm{C}\right.$ and $\left.80^{\circ} \mathrm{C}\right)$. The Pt loading for the anode and cathode were $0.05 \mathrm{mg} / \mathrm{cm}^{2}$ and $0.4 \mathrm{mg} / \mathrm{cm}^{2}$, respectively. To assure the same water content in the Nafion membrane, the inlet RHs were fixed at $50 \%$ on both the anode and cathode during constantcurrent operation at $10 \mathrm{~A}$. The $\varepsilon$-caprolactam was fed into the cell on the cathode via a nebulizer and a micro-syringe peristaltic pump. The $\varepsilon$-caprolactam was mixed with dry air gas and the relative humidity was controlled by the flow rate of the $\varepsilon$-caprolactam solution. The cell voltage and the high-frequency resistance (HFR) were recorded during the infusion of $\varepsilon$-caprolactam at $10 \mathrm{~A}$. Cyclic voltammograms $(\mathrm{CVs})$ were also recorded to quantify the effects on the Pt/C electrode.

\section{Results and Discussion}

Temperature effects on the ion exchange.- Figure 2 shows the $\mathrm{UV}$-vis spectra, indicating that $\varepsilon$-caprolactam was absorbed into the Nafion membranes. Figures 2 a shows no changes in the UV-vis maximum-intensity peaks (at $215 \mathrm{~nm}$ ) for $5 \mathrm{mN} \varepsilon$-caprolactam solution (control experiment) stored at $25^{\circ} \mathrm{C}$ and $90^{\circ} \mathrm{C}$ for 1,2 and 5 days. Figure $2 \mathrm{~b}$ shows that at $25^{\circ} \mathrm{C}$, the maximum-intensity peak shifted slightly to a lower wavelength after a piece of N115 $\left(2 \times 2 \mathrm{~cm}^{2}\right)$ has been soaking in the $5 \mathrm{mN} \varepsilon$-caprolactam solution for 2 and 5 days. The temperature effect is shown by the dotted lines in Figure 2c, where the intensity of peak in the UV-vis spectrum, representing $\varepsilon$-caprolactam concentration, dramatically decreased when $\mathrm{N} 115$ was soaked in a $\varepsilon$-caprolactam solution at $90^{\circ} \mathrm{C}$ for 2 and 5 days. This effect was accelerated by the addition of sulfuric acid $(50 \mathrm{mM})$, as shown in Figure 2d.

We hypothesize that a ring-opening reaction of lactam (-NH$\mathrm{C}=\mathrm{O}-$ ) becomes more favorable as the temperature increases (i.e., the reaction is endothermic), similar to the ring-opening reaction of lactone with a molecular structure of $-\mathrm{O}-\mathrm{C}=\mathrm{O}-$. The ringopening reaction of lactam, which is the acid-catalyzed hydrolysis of an amide, has been extensively investigated and reviewed. ${ }^{42-45}$ The $\varepsilon$-caprolactam becomes $\varepsilon$-amino caproic acid, and the amine $\left(-\mathrm{NH}_{2}\right)$ of the $\varepsilon$-amino caproic acid can be hydrolyzed to quaternary amine $\left(-\mathrm{NH}_{3}{ }^{+}\right)$under acidic conditions. In a higher-temperature environment, more $\varepsilon$-amino caproic acid can be produced. ${ }^{42}$ In Figure 3 , a schematic of a possible ring-opening reaction of the 

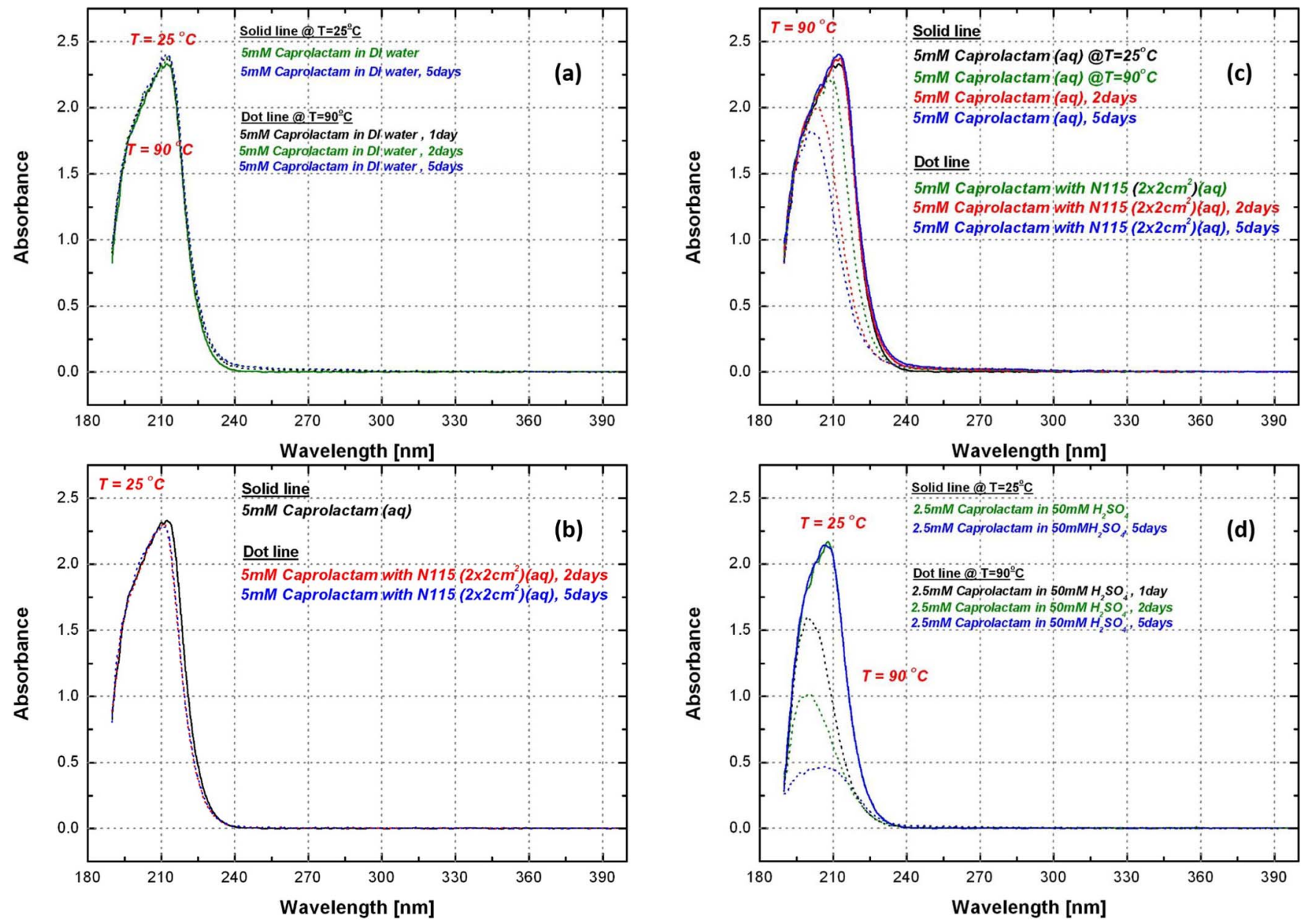

Figure 2. UV-vis. spectrum of various concentration of $\varepsilon$-caprolactam in DI water (a) $5 \mathrm{mM}$ solutions stored at ambient temperature and $90^{\circ} \mathrm{C}$ (b) $5 \mathrm{mM}$ after soaking a piece of $\mathrm{N} 115\left(2 \times 2 \mathrm{~cm}^{2}\right)$ at ambient temperature (c) $5 \mathrm{mM}$ after soaking a piece of $\mathrm{N} 115\left(2 \times 2 \mathrm{~cm}^{2}\right)$ at $90^{\circ} \mathrm{C}(\mathrm{d}) 2.5 \mathrm{mM}$ after soaking a piece of $\mathrm{N} 115\left(2 \times 2 \mathrm{~cm}^{2}\right)$ at $90^{\circ} \mathrm{C}$ in addition of $50 \mathrm{mM} \mathrm{H}_{2} \mathrm{SO}_{4}(\mathrm{aq})$.

$\varepsilon$-caprolactam, followed by electrostatic interaction with a sulfonic acid group in the PEM, is shown. The ion-exchange reaction between the protonated quaternary amine $\left(-\mathrm{NH}_{3}{ }^{+}\right)$of $\varepsilon$-amino caproic acid and the sulfonic acid group in the PEM may occur and lead to a decrease in the proton conductivity. However, the ion exchange may be more difficult compared to other small metal cations such as $\mathrm{K}^{+}, \mathrm{Na}^{+}, \mathrm{Ca}^{2+}$ and $\mathrm{Fe}^{3+}$ because of the steric hindrance from the bulkier and longer chemical structure of the $\varepsilon$-amino caproic acid.

In-plane membrane conductivities of NRE211 membranes $(0.9 \mathrm{~cm} \times 4.5 \mathrm{~cm})$, soaked in $0.1 \mathrm{M}$ e-caprolactam solutions at $23^{\circ} \mathrm{C}$ and $90^{\circ} \mathrm{C}$, were measured to verify the temperature effect of $\varepsilon$-caprolactam on the Nafion membrane. Figure 4 shows the effect of soaking temperature on membrane conductivity as a function of $\mathrm{RH}$ for various species (i.e., sodium, ammonium, and $\varepsilon$-caprolactam). The in-plane membrane conductivity of the NRE211 exhibits a log-linear proportionality with the RH: $\log \sigma=\mathrm{aRH}+\mathrm{b}$, where $\mathrm{a}$ and $\mathrm{b}$ are constants. The constant a in this equation for all cases in Figure 4 is listed in Table I. A large slope indicates a greater dependence of the membrane conductivity on the RH. The conductivity of the NRE211 soaked in the $\varepsilon$-caprolactam solution at $90^{\circ} \mathrm{C}$ (line (d) with open circles in Figure 4) is two orders of magnitude lower than that of the membrane soaked at $23^{\circ} \mathrm{C}$ (line (d) with closed dots). No such differences were observed for any of the other cationic forms (i.e., $\mathrm{Na}^{+}$, $\mathrm{NH}_{3}{ }^{+}$) of the NRE211 membranes at different temperatures. The conductivities of all other cationic forms $\left(\mathrm{Na}^{+}, \mathrm{NH}_{3}{ }^{+}\right)$of the NRE211 membranes was 100 times lower than pristine at an $\mathrm{RH}$ of $50 \%$. The greatest conductivity loss of $\varepsilon$-caprolactam at $90^{\circ} \mathrm{C}$ in the NRE211 with the lowest exchange percent (30\% vs. $99 \%$ for all others) may

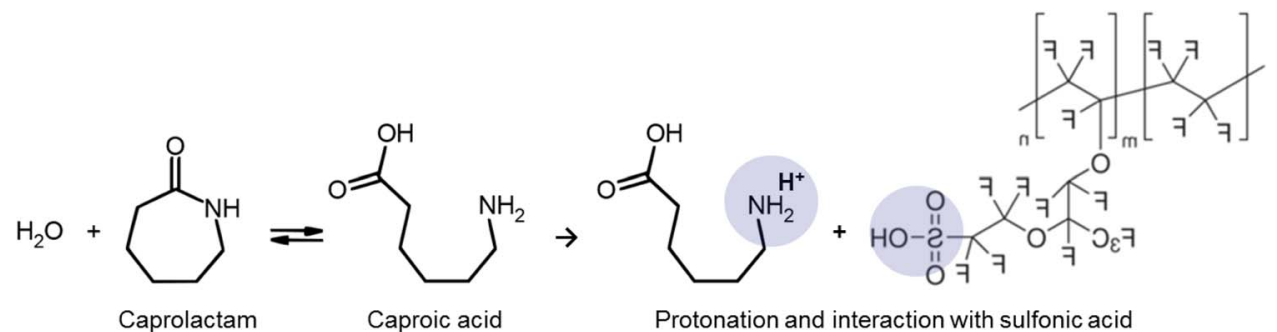

Figure 3. Schematic of a ring open mechanism of an $\varepsilon$-caprolactam followed by a possible electrostatic interaction with sulfonic acid in PEM. 


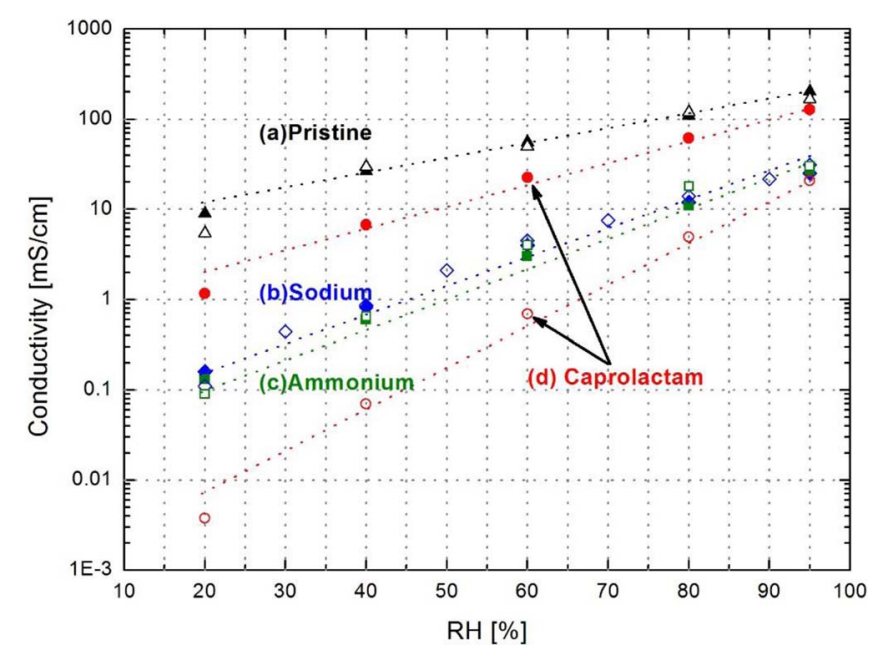

Figure 4. Effect of soaking temperature on NRE211 conductivity as a function of RH for various contaminants: (a) pristine (b) sodium (c) ammonium (d) $\varepsilon$ caprolactam: closed and open dots represent ambient temperature and $90^{\circ} \mathrm{C}$ soaks, respectively.

result from the steric hindrance of the $\varepsilon$-amino caproic acid or the $\varepsilon$-caprolactam.

In our previous aniline study ${ }^{31,35}$, we compared, as a function of $\mathrm{RH}$, the water contents in N117 membranes with the same acid sites exchanged with aniline and sodium. The water contents of the anilineexchanged N117 membranes were 100 times lower than those of the sodium-exchanged N117 membranes. We attributed the lower water content to the steric hindrance caused by the size of the species and to the hydrophobic functionality of the aniline.

For the temperature effect on the hydrolysis of $\varepsilon$-caprolactam, one can use the data in Table II to calculate the equilibrium constants for the partition between the closed ring and open ring of $\varepsilon$-caprolactam. The $\Delta \mathrm{H}_{\mathrm{rxn}}$ value for the open ring reaction of $\varepsilon$-caprolactam was calculated to be $8.85 \mathrm{~kJ} / \mathrm{mol}$ (endothermic reaction) on the basis of the values in Table II. The $\mathrm{K}_{90^{\circ} \mathrm{C}} / \mathrm{K}_{25^{\circ} \mathrm{C}}$ ratio for the ring opening is 2.0 when calculated according to the Van't Hoff equation in equation 1. Notably, the Gibbs free energy in Table II is positive for both temperatures because $\Delta \mathrm{H}>0,-\mathrm{T} \Delta \mathrm{S}<0$ indicates an unfavorable enthalpy change (i.e., an endothermic reaction) and a favorable entropy change (i.e., an increase in disorder as a result of the ring-opening reaction).

$$
\begin{gathered}
\ln \left(\frac{K_{2}}{K_{1}}\right)=-\frac{\Delta H_{r x n}}{R}\left(\frac{1}{T_{2}}-\frac{1}{T_{1}}\right) \\
K=\exp \left(\frac{-G}{R T}\right)=\exp \left[\frac{(S-H / T)}{R}\right]
\end{gathered}
$$

In Figure 5, the isotherm of Nafion membranes for $\varepsilon$-caprolactam at $90^{\circ} \mathrm{C}$ indicated a higher affinity toward the PEM relative to other single-charged cations such as $\mathrm{Na}^{+}$and $\mathrm{NH}_{3}{ }^{+}$when the mole fraction of $\varepsilon$-caprolactam in solution exceeded 0.4 . The similarity between the chemical structures of the Nafion membranes under acidic conditions and the carboxylic acid (-COOH) group of $\varepsilon$-amino caproic acid is one reason for the higher affinity of $\varepsilon$-caprolactam toward the PEM at $90^{\circ} \mathrm{C}$. The larger size of $\varepsilon$-caprolactam might be another reason for its
Table I. Slopes (constant a in the equation $\log (\sigma)=\mathrm{aRH}+\mathrm{b})$ of membrane conductivity as a function of RH for NRE211 in the presence of various species.

$\begin{array}{ccccc} & & & \text { (d) } \varepsilon \text {-caprolactam } & \varepsilon \text {-caprolactam } \\ \text { (a) Pristine } & \text { (b) } \mathrm{Na} & \text { (c) } \mathrm{NH}_{3} & \left(23^{\circ} \mathrm{C}\right) & \left(90^{\circ} \mathrm{C}\right) \\ 0.0188 \pm 0.002 & 0.0277 & 0.0311 & 0.0267 & 0.0493\end{array}$

higher affinity given that potassium ion $\left(\mathrm{K}^{+}\right)$has a higher affinity for the PEM than does sodium $\left(\mathrm{Na}^{+}\right)$because of the larger radius, and thus smaller hydration radius, of potassium. ${ }^{47-49}$ The isotherm of Nafion membranes for $\varepsilon$-caprolactam at ambient temperature, however, indicated a lower affinity for the PEM. The difference in affinities of the $\varepsilon$-caprolactam toward the PEM at different temperatures may indicate a temperature effect on the ring-opening reaction.

ATR-IR studies for \&-caprolactam-absorbed Nafion membranes.As shown in Figure 6a, the ATR-IR spectrum of the $\varepsilon$-caprolactamabsorbed membrane shows a shift of the $\mathrm{SO}_{3}{ }^{-}$stretching peak at $1057 \mathrm{~cm}^{-1}$ because of the electrostatic interactions with the sulfonic group $\left(\mathrm{R}-\mathrm{SO}_{3}{ }^{-}\right)$. This shift is also observed in the spectra of other cationic forms of Nafion membranes. This behavior is attributed to a decrease in the polarization of the sulfonic group $\left(\mathrm{R}_{-} \mathrm{SO}_{3}{ }^{-}\right)$by the protonated quaternary amine group. ${ }^{50-54}$ The $1600-1700 \mathrm{~cm}^{-1}$ region shows the broadly overlapped $\mathrm{C}=\mathrm{O}$ stretching peaks of ketone (1750-1680 $\left.\mathrm{cm}^{-1}\right)$, carboxylic acid $\left(1780-1710 \mathrm{~cm}^{-1}\right)$, amide (1670$\left.1650 \mathrm{~cm}^{-1}\right)$, and asymmetric carbonyl $\left(1655 \mathrm{~cm}^{-1}\right)$ vibrations, which support the presence of the protonated $\varepsilon$-caprolactam in the membrane. Whether the chemical structure is closed-ring or open-ring cannot be clearly determined. Notably, however, the spectra of aliphatic longchain carboxylic acids exhibit bands in the range of $1345-1180 \mathrm{~cm}^{-1}$ in the solid phase, and the number of weak bands is related to the length of the chain. ${ }^{54}$ Here, three weak bands are observed in the 1300$1100 \mathrm{~cm}^{-1}$ region of the spectrum for the $\varepsilon$-caprolactam-absorbed membrane, which could represent 6 carbon atoms of the aliphatic $\varepsilon$ amino carboxylic acid. For acids with an even number of carbon atoms in the solid phase, the number of bands observed in this region equals half the number of carbon atoms; i.e., $\varepsilon$-amino caproic acid contains 6 carbon atoms, which may be revealed by the 3 weak bands in the range of $1345-1180 \mathrm{~cm}^{-1} .{ }^{54}$ Details of the assigned peaks of the ATR-IR spectra for the $\varepsilon$-caprolactam-absorbed Nafion membranes are shown in Table III.

To verify the chemical structure of the absorbed $\varepsilon$-caprolactam in the previously described membrane, the $\varepsilon$-caprolactam was extracted by dissolving the membrane in a methanol solution, followed by ATR-IR measurements. For reference, ATR-IR spectra of $1 \mathrm{mM} \varepsilon$-caprolactam and $\varepsilon$-amino caproic acid in methanol were also compared, as shown in Figure 6b. In the band region of 1650$1630 \mathrm{~cm}^{-1}$, the spectrum of the solution of the $\varepsilon$-caprolactam dissolved in methanol (line (a)) showed N-H and $\mathrm{C}=\mathrm{O}$ stretching vibration peaks. A shift of the band peaks to the $1690-1655 \mathrm{~cm}^{-1}$ region was observed for the sample solutions (lines (b), (c), and (d)), which is attributed to the $\mathrm{C}=\mathrm{O}$ stretching and vibration bands of the aliphatic carboxylic acid. This peak shift in the region of 1690$1630 \mathrm{~cm}^{-1}$ was observed in the spectra of all of the sample solutions (lines (b), (c), (d)), with the exception of the spectrum of the $\varepsilon$-caprolactam solution dissolved in methanol (line (a)). Thus, we believe that the peak shift in the region of $1690-1630 \mathrm{~cm}^{-1}$

Table II. Kinetic constants of $\varepsilon$-caprolactam for ring opening reaction. ${ }^{44}$

Kinetic constants of the rate equation

$\mathrm{G}[\mathrm{kJ} / \mathrm{mol}]$

\begin{tabular}{ccccccc}
\hline Reaction & $\mathrm{A}\left[\mathrm{kg} / \mathrm{mol}^{2} \cdot \mathrm{hr}\right]$ & $\mathrm{E}[\mathrm{kJ} / \mathrm{mol}]$ & $\mathrm{H}[\mathrm{kJ} / \mathrm{mol}]$ & $\mathrm{S}[\mathrm{kJ} / \mathrm{mol} \cdot \mathrm{K}]$ & $\overline{23}$ & $90^{\circ} \mathrm{C}$ \\
\hline Ring opening & $1.69 \mathrm{E}+06$ & 88.09 & 8.85 & -0.033 & 18.59
\end{tabular}


in Figure 6b supports the presence of the open-ring structure of $\varepsilon$-caprolactam (i.e., $\varepsilon$-amino caproic acid) in Nafion membranes.

Interactions with the Pt/C catalyst electrode.- CVs of polycrystalline Pt (Figure 7b) and the carbon-supported Pt electrode (loading $=0.02 \mathrm{mg} / \mathrm{cm}^{2}$ ) (Figures 7a, 7c, and 7d) were obtained for different concentrations of $\varepsilon$-caprolactam solutions in $0.1 \mathrm{M} \mathrm{HClO}_{4}$ electrolyte to investigate the effects of $\varepsilon$-caprolactam by adsorption on $\mathrm{Pt} / \mathrm{C}$ or electrochemical reactions. Both electrodes showed $\varepsilon$-caprolactam effect on the hydrogen desorption/adsorption regions at room temperature; however, no significant electrochemical surface area (ECSA) losses (less than 20\%, see Table IV) were observed in Figures 7a or $7 \mathrm{~b}$. The $\mathrm{Pt}$ oxidation and $\mathrm{PtO}_{\mathrm{x}}$ reduction peaks also decreased as the $\varepsilon$-caprolactam concentration was increased, as shown in Figures $7 \mathrm{c}$ and $7 \mathrm{~d}$, obtained at two different temperatures, $23^{\circ} \mathrm{C}$ and $73.5^{\circ} \mathrm{C}$, respectively. Additionally, an oxidation shoulder peak was commonly observed at approximately $0.25 \mathrm{~V}$. The shoulder peak at $0.25 \mathrm{~V}$ is more clearly observed in the $\mathrm{CV}$ measured at higher temperature $\left(73^{\circ} \mathrm{C}\right)$ and for polycrystalline $\mathrm{Pt}$, as shown in Figures $7 \mathrm{~d}$ and $7 \mathrm{~b}$, respectively. Therefore, we assumed that the oxidation peak at approximately 0.25 $\mathrm{V}$ is more related to the $\varepsilon$-amino caproic acid than to the $\varepsilon$-caprolactam (recall the endothermic ring-opening reaction of $\varepsilon$-caprolactam). The diminished hydrogen desorption/adsorption and $\mathrm{Pt}$ oxidation/PtOx reduction peaks may be a result of the adsorption of a carboxylic acid $(-\mathrm{COOH})$ group of the $\varepsilon$-amino caproic acid. The Pt catalyst may aid in oxidizing the carboxylic acid at a relatively low electro-potential after the carboxylic acid $(-\mathrm{COOH})$ functional group has adsorbed onto the $\mathrm{Pt} / \mathrm{C}$ electrode. Thus, a proton can be produced from the carboxylic acid oxidation as follows: $-\mathrm{COOH}+\mathrm{Pt} \rightarrow-\mathrm{COO}-\mathrm{Pt}+\mathrm{H}^{+}$ $+\mathrm{e}^{-}$. The increase in the current density from $1.0 \mathrm{~V}$ to $1.2 \mathrm{~V}$ may be explained by the oxidation of the carboxylic acid to produce carbon dioxide: -COO-Pt $\rightarrow \mathrm{CO}_{2}+\mathrm{e}^{-}$. Notably, this adsorption behavior of a carboxylic acid on a gold ( $\mathrm{Au}$ ) electrode has been reported in another study. ${ }^{55}$ At $\mathrm{pH} 2$, the ECSA loss for the Pt/C electrode (i.e., less than 40\%) is greater than that at $\mathrm{pH} 1$ (i.e., less than 20\%) in the presence of the $\varepsilon$-caprolactam, as shown in Table IV. Because the $\mathrm{pK}_{\mathrm{a}}$ of the carboxylic acid group of the $\varepsilon$-amino caproic acid is $2-3$, the carboxylic acid cannot be dissociated at $\mathrm{pH} 1$ (i.e., $\mathrm{pH}<\mathrm{pKa}$ ). Thus, the adsorption of carboxylic acid $(-\mathrm{COOH})$ onto the surface of the Pt electrode may be more difficult than the adsorption of carboxylate anion $\left(-\mathrm{COO}^{-}\right)$

The kinetic current of the oxygen reduction reaction (ORR) on the $\mathrm{Pt} / \mathrm{C}$ electrode was also measured in the presence of $\varepsilon$ caprolactam in perchloric acid solution $(1 \mathrm{mM})$, as shown in Figure 8 . The limiting currents and Tafel slopes of the $\mathrm{Pt} / \mathrm{C}$ cata-

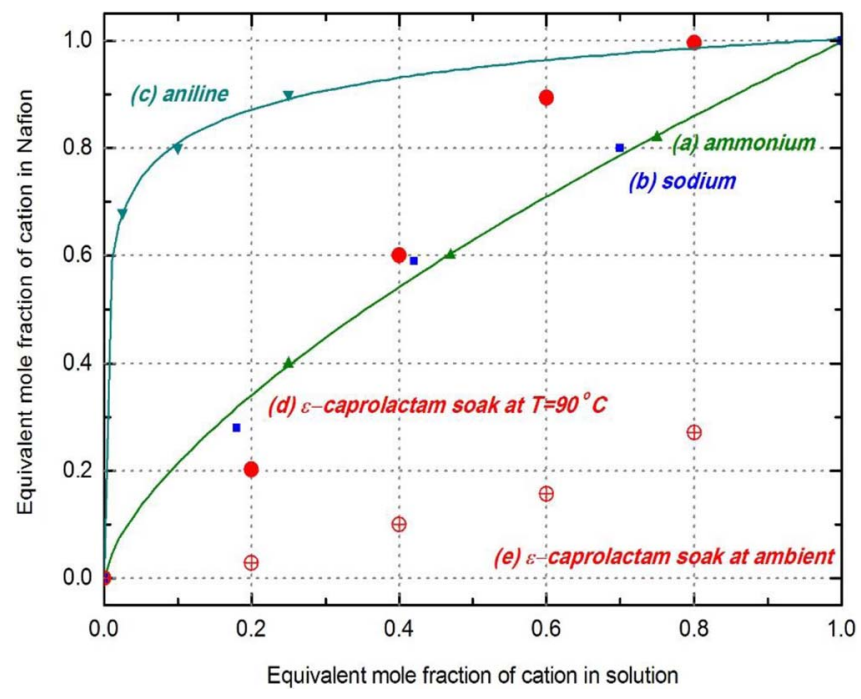

Figure 5. Comparison of ion-exchange isotherm of Nafion membrane for (a) ammonium (b) sodium (c) aniline (d) $\varepsilon$-caprolactam. lyst electrode are affected by the $\varepsilon$-caprolactam, but not substantially. The current change at $0.9 \mathrm{~V}$ is less than $15 \%$ in $1.0 \mathrm{mM} \varepsilon$-caprolactam, as shown in Figure 8. We believe that the open-ring structure of $\varepsilon$ caprolactam results in the activity loss of the $\mathrm{Pt} / \mathrm{C}$ catalyst via the adsorption of carboxylate anion $\left(-\mathrm{COO}^{-}\right)$or carboxylic acid $(-\mathrm{COOH})$. However, the ion exchange of a protonated quaternary amine $\left(-\mathrm{NH}_{3}{ }^{+}\right)$ with acid sites also increased mass transport resistance in the $\mathrm{Pt} / \mathrm{C}$ electrode.

Study of the functional groups of $\varepsilon$-caprolactam.- To understand the effects of $\varepsilon$-caprolactam on the $\mathrm{Pt} / \mathrm{C}$ electrode according to its functional groups, we chose two model compounds for comparison: ammonia $\left(\mathrm{NH}_{3}\right)$ and acetic acid $\left(\mathrm{CH}_{3} \mathrm{COOH}\right)$. These chemicals represent the amide $\left(-\mathrm{NH}_{2}\right)$ group and the carboxylic acid group of $\varepsilon$-amino caproic acid (i.e., the open-ring structure of $\varepsilon$-caprolactam). The $\mathrm{CV} s$ in Figure 9a also show the redox peak at $0.25 \mathrm{~V}$ in the presence of $1 \mathrm{mM}$ acetic acid in $\mathrm{HClO}_{4}$, whereas the intensity of the hydrogen adsorption peak of the $\mathrm{Pt} / \mathrm{C}$ electrode is reduced. This similarity in the CVs may indicate the adsorption of the carboxylic acid onto the surface of Pt. Additionally, the Pt oxidation and PtOx reduction formation are suppressed in acetic acid. However, both could be mostly recovered after the electrodes were rinsed with DI water, transferred to a clean electrolyte solution, and followed by the application of a ten potential cycles to $1.20 \mathrm{~V}$.

In Figure 9b, the CVs, after the introduction of ammonia gas into the electrolyte over a period of $10 \mathrm{~min}$, showed a $20 \%$ loss of ECSA. Moreover, no further loss of ECSA was observed after the electrolyte was fully saturated with ammonia gas $\left(\approx 10^{5}\right.$ monolayer). This loss may represent the ammonium $\left(\mathrm{NH}_{4}{ }^{+}\right)$interaction with the acid sites of the Nafion ionomer in the $\mathrm{Pt} / \mathrm{C}$ electrode. That is, we do not believe that the ammonium cation adsorbed onto the Pt surface; however, a structural change of the ionomer (a "blockage secondary effect" on the proton pathway) in the $\mathrm{Pt} / \mathrm{C}$ electrode may be possible. Other peaks related to electrochemical reactions of ammonia were not observed in the CVs. The correlation between the results described in this section on the CV studies of the model compounds (i.e., acetic acid and ammonia) and the $\varepsilon$-caprolactam effects on the $\mathrm{Pt} / \mathrm{C}$ electrode suggests that the ion exchange by the protonated amine and the adsorption of the carboxylic acid $(-\mathrm{COOH})$ of the open-ring structure of the $\varepsilon$-caprolactam are potential contamination mechanisms in the $\mathrm{Pt} / \mathrm{C}$ electrode of PEMFCs.

In situ study of $\varepsilon$-caprolactam effects on PEMFCs. - Cell voltage and high-frequency resistance (HFR) responses at two different cell temperatures $\left(50^{\circ} \mathrm{C}\right.$ and $\left.80^{\circ} \mathrm{C}\right)$ were recorded during the infusion of $\varepsilon$-caprolactam at constant current $(10 \mathrm{~A})$, using a stoichiometry of $2.0 / 2.0$, back pressure of $150 / 150 \mathrm{kPa}$, and $50 \% \mathrm{RH}$ for anode/cathode, respectively. A comparison of lines (a) no contaminants, (b) $18 \mu \mathrm{mol} / \mathrm{h}$ of $\varepsilon$-caprolactam, and (c) $78 \mu \mathrm{mol} / \mathrm{h}$ of $\varepsilon$-caprolactam in Figure 10 reveals that, as the feed rate of the $\varepsilon$-caprolactam under the same conditions increases, the voltage loss (i.e., $V_{\text {pristine }}-V_{\text {contamination }}$ ) increases. The interesting aspect of this $\varepsilon$-caprolactam effect on performance loss is the temperature effect shown in the comparison of lines (b) $80^{\circ} \mathrm{C}$ and (d) $50^{\circ} \mathrm{C}$ for the same molar feed rate (i.e., $18 \mu \mathrm{mol} / \mathrm{h}$ ) of $\varepsilon$-caprolactam. The voltage loss at $80^{\circ} \mathrm{C}$ is greater than the loss at $50^{\circ} \mathrm{C}$. This observation has a similar explanation as the contamination effect, which is greater at a higher temperature because of the favorable ring-opening reaction of the $\varepsilon$-caprolactam. Recall that amino $\varepsilon$-caproic acid can be produced by the endothermic ring-opening reaction of $\varepsilon$-caprolactam in the presence of water and acid. The HFR increase also indicates membrane contamination by the ion-exchange mechanism. Although this occurrence can be caused by the absorption mechanism, we speculate that the continuous linear voltage loss may indicate that it is caused by the ion-exchange mechanism. The reasoning for this assumption is that the maximum coverage of acid sites in the PEM is 1.0 for ion exchange and is typically less than 1.0 for absorption. In a previous study, the voltage decay induced by absorption exhibited Langmuir behavior (see diethylene glycol monoethyl ether contamination in Ref. 35). 
(a)
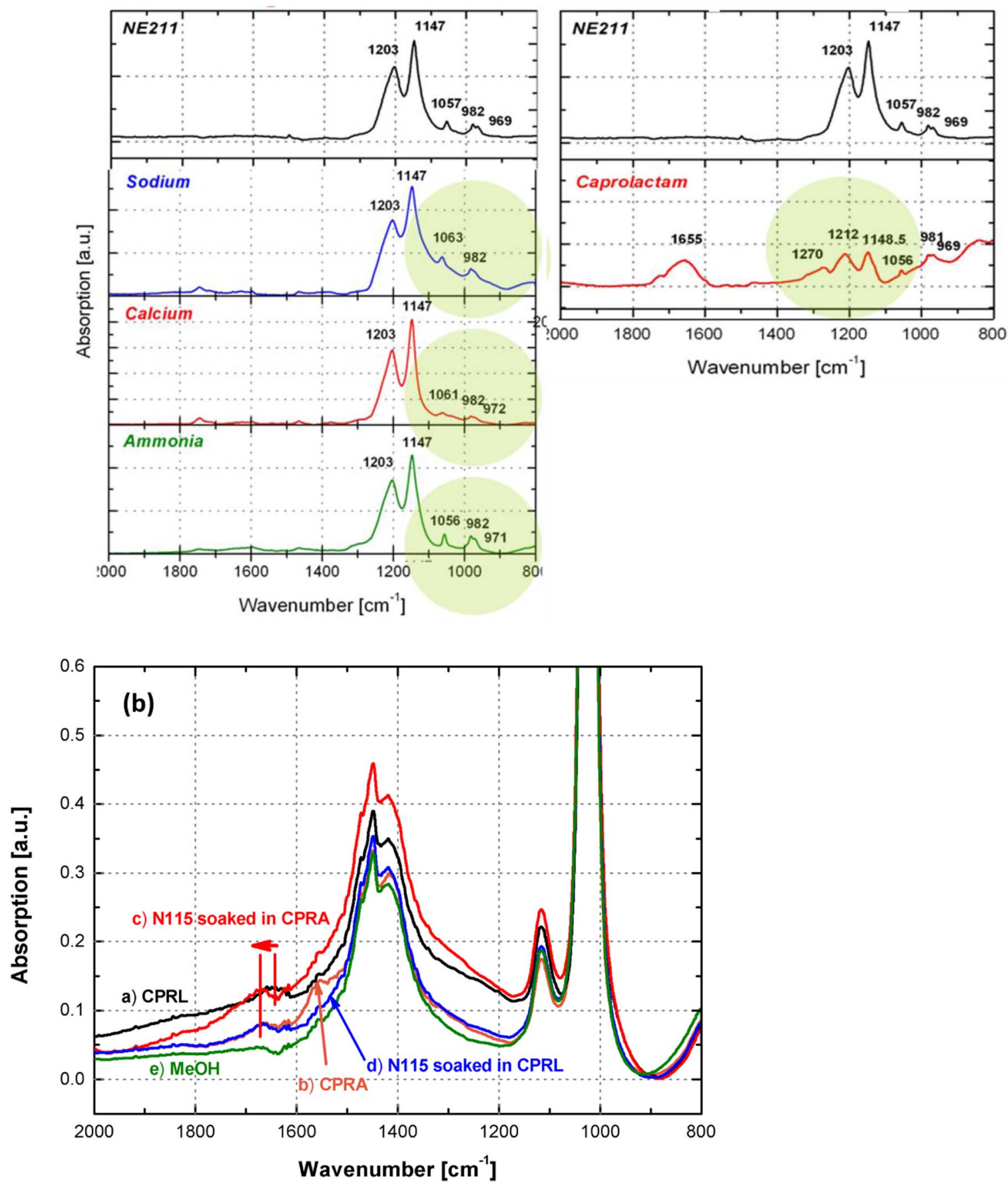

Figure 6. ATR-IR spectrums of (a) various forms of NE211 (b) various solutions in methanol: a) $\varepsilon$-caprolactam b) $\varepsilon$-amino caproic acid c) extract $\varepsilon$-amino caproic acid from N115 d) extract $\varepsilon$-caprolactam from N115 e) methanol.

Notably, we chose a $50 \%$ RH (i.e., 0.5 water vapor activity) to ensure the same water content in the PEMs at different temperatures. Two fitting curves of measured water uptake for N117 membranes at $30^{\circ} \mathrm{C}$ and $80^{\circ} \mathrm{C}^{56,57}$ and for NRE2 12 membranes at $50^{\circ} \mathrm{C}$ and $90^{\circ} \mathrm{C}$ are shown as dots in Figure 11. The water uptake in the PEM shows consistency at RH values less than $50 \%$, whereas significant discrepancies arise at $\mathrm{RH}$ values greater than $50 \%$. Moreover, we expect the same amount of water production at the same current (i.e., $\mathrm{I}=10 \mathrm{~A}$ ) operation on the cathode by ORR. Thus, we can exclude the influence of water to observe only the temperature effect on the $\varepsilon$-caprolactam infusion experiments. We took this step because of our concern of possible rinse effects induced by a greater water uptake in the PEM at high temperatures. The molar flow rate of the water vapor in the feed air gas at $80^{\circ} \mathrm{C}$ was still greater than that of the water vapor at $50^{\circ} \mathrm{C}(\approx$ $46.3 \mu \mathrm{mol} / \mathrm{s}>10.6 \mu \mathrm{mol} / \mathrm{s}$ ), even though the RHs were equal. Recall that the stoichiometry and back pressure were also equal. However, a greater voltage loss at $80^{\circ} \mathrm{C}$ was observed even when a larger amount of water vapor was fed into the cell. Thus, we believe that the ringopening reaction of the $\varepsilon$-caprolactam with the aid of water and acid plays a key role in the contamination of PEMFCs.

The in situ CV measurements (not shown in this paper) before $(0 \mathrm{~h})$ and after infusion $(14.5 \mathrm{~h}$ in Figure 10$)$ revealed $40 \%$ (line c) 
Table III. Assignments of ATR-IR peaks of $\varepsilon$-caprolactam exchanged form Nafion. ${ }^{54}$

\begin{tabular}{|c|c|c|c|}
\hline \multirow[b]{2}{*}{ Assignments } & \multicolumn{2}{|c|}{ Peak $\left[\mathrm{cm}^{-1}\right]$} & \multirow[b]{2}{*}{ Remark } \\
\hline & Pristine & $\varepsilon$-caprolactam & \\
\hline Symmetric C-O-C stretching vibration & 969 & $969(\mathrm{w})$ & \\
\hline Asymmetric C-O-C stretching vibration & 982 & 981 & \\
\hline Symmetric $-\mathrm{SO}_{3}{ }^{-}$stretching & 1057 & 1056 & \\
\hline Asymmetric carbonyl vibration & - & 1655 & \\
\hline Symmetric $\mathrm{CF}_{2}$ band & 1147 & 1149 & Aliphatic long-chain-COOH \\
\hline Asymmetric $\mathrm{CF}_{2}$ band & 1203 & 1212 & Aliphatic long-chain $-\mathrm{COOH}$ \\
\hline Keton $\mathrm{C}=\mathrm{O}$ stretching & \multicolumn{2}{|c|}{$1750-1680$} & \\
\hline Carboxylic acid $\mathrm{C}=\mathrm{O}$ stretching & \multicolumn{2}{|c|}{$1780-1710$} & \\
\hline Primary amide $\mathrm{C}=\mathrm{O}$ stretching & \multicolumn{2}{|c|}{$1670-1650$} & \\
\hline Alkyl C-H stretching & \multicolumn{2}{|c|}{$2950-2850$} & \\
\hline \multirow[t]{2}{*}{ Primary aliphatic amide deformation vibration } & \multicolumn{2}{|c|}{$850-810$} & \\
\hline & \multicolumn{2}{|c|}{$\begin{array}{l}2960-2900 \\
2920-2800\end{array}$} & $\begin{array}{l}\text { Asym } \mathrm{CH}_{2} \text { str. } \\
\mathrm{Sym} \mathrm{CH}_{2} \text { str. }\end{array}$ \\
\hline \multirow[t]{2}{*}{$-\mathrm{CH}_{2} \mathrm{NH}_{3}{ }^{+}, \mathrm{N}-\mathrm{H}^{+}$deformation and vibration } & \multicolumn{2}{|c|}{$1635-1585,1615-1565$} & Asym $\mathrm{NH}_{3}{ }^{+}$def vib. \\
\hline & \multicolumn{2}{|c|}{$1280-1150,1135-1005,1100-930$} & $\begin{array}{c}\mathrm{Sym} \mathrm{NH}_{3}{ }^{+} \text {def vib. } \\
\mathrm{NH}_{3}{ }^{+} \text {rocking vib., } \mathrm{CN} \text { str vib. }\end{array}$ \\
\hline Aliphatic long-chain carboxylic acids $(-\mathrm{COOH})$ & \multicolumn{2}{|c|}{$1345-1180$} & $\begin{array}{c}\text { In the solid phase, } \mathrm{CH}_{2} \text { def. vib., number } \\
\text { of bands determined by aliphatic chain } \\
\text { length }\end{array}$ \\
\hline
\end{tabular}
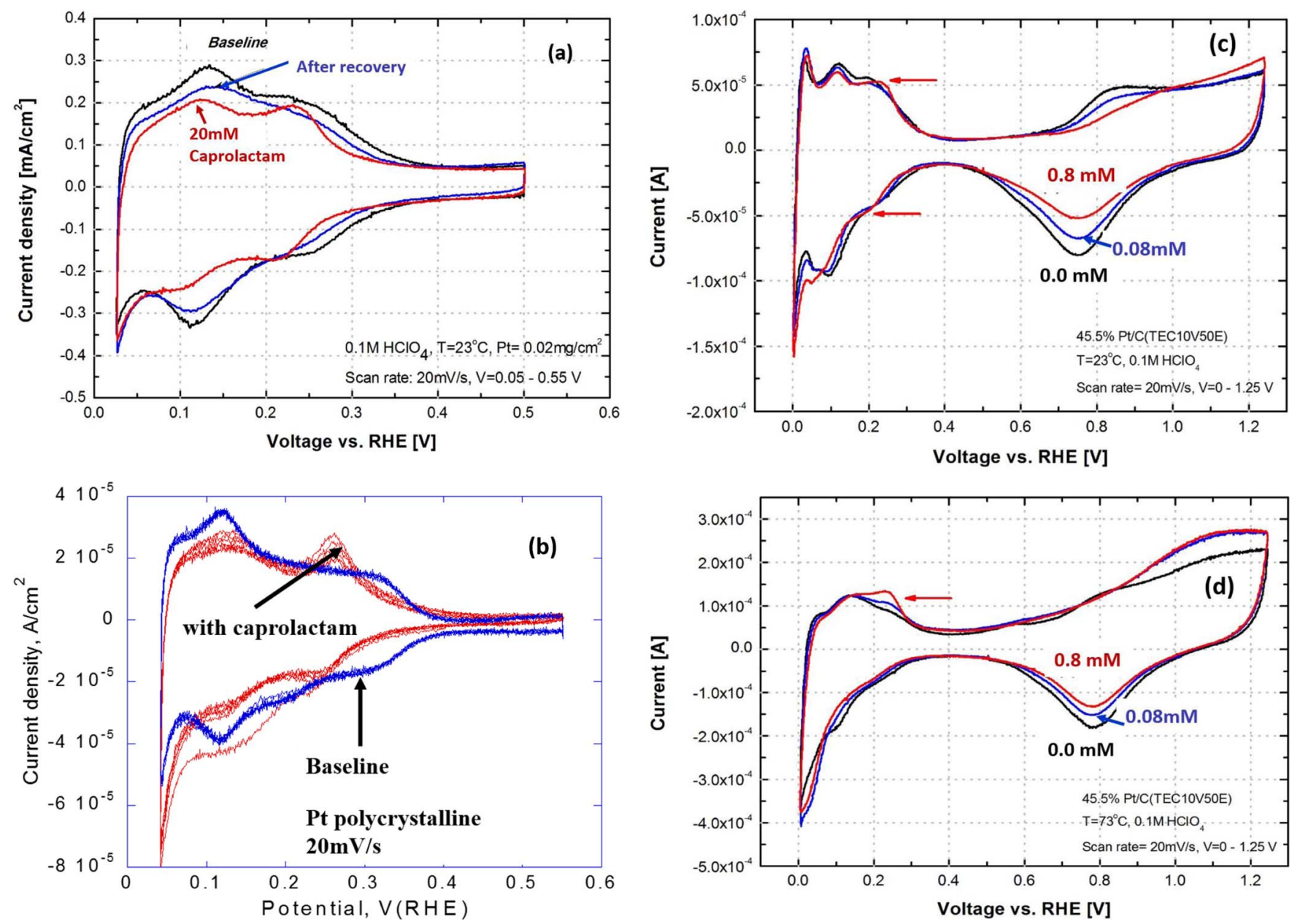

Figure 7. $\varepsilon$-caprolactam effects on cyclic voltammograms of Pt/C catalyst electrode: partial CV scans of (a) $45.5 \% \mathrm{Pt} / \mathrm{C}$ (b) polycrystalline Pt, full CV scans of $45.5 \% \mathrm{Pt} / \mathrm{C}$ at (c) ambient temperature (d) $73^{\circ} \mathrm{C}$. 


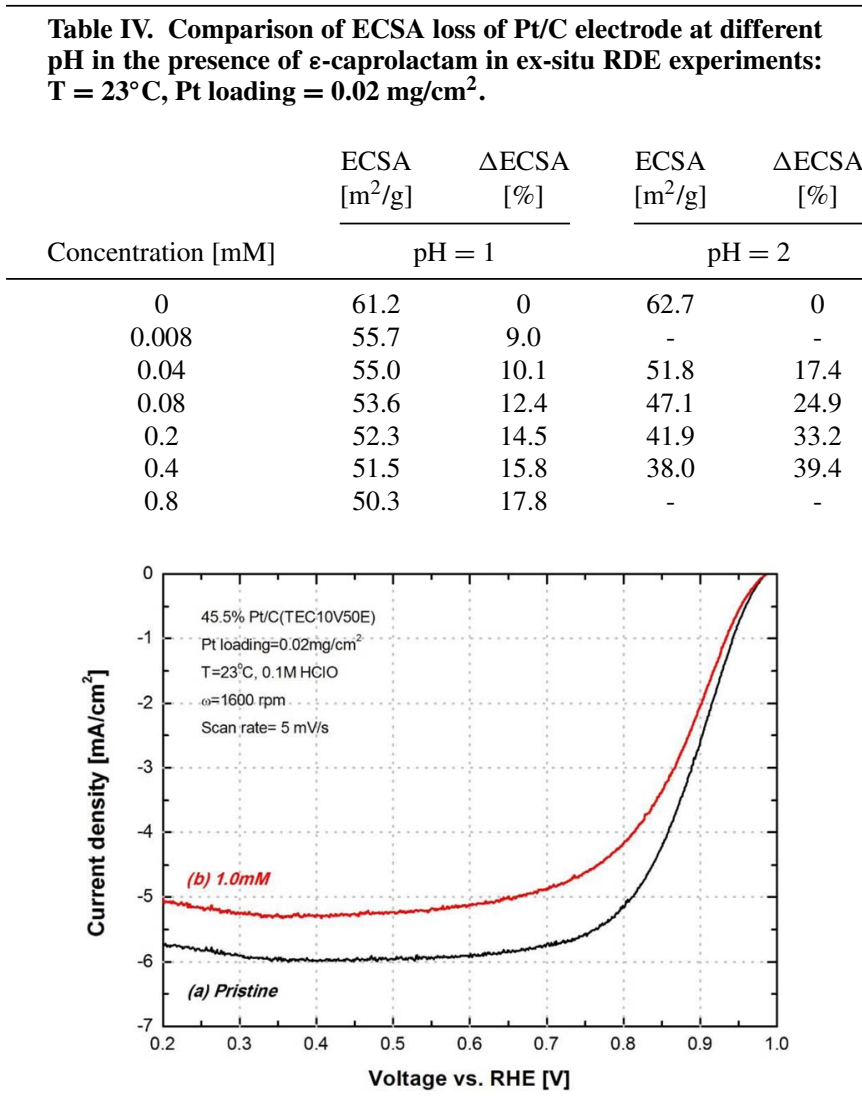

Figure 8. Oxygen reduction reaction curve for $45.5 \% \mathrm{Pt} / \mathrm{C}$ catalyst in the (a) absence and (b) presence of $1.0 \mathrm{mM} \varepsilon$-caprolactam.
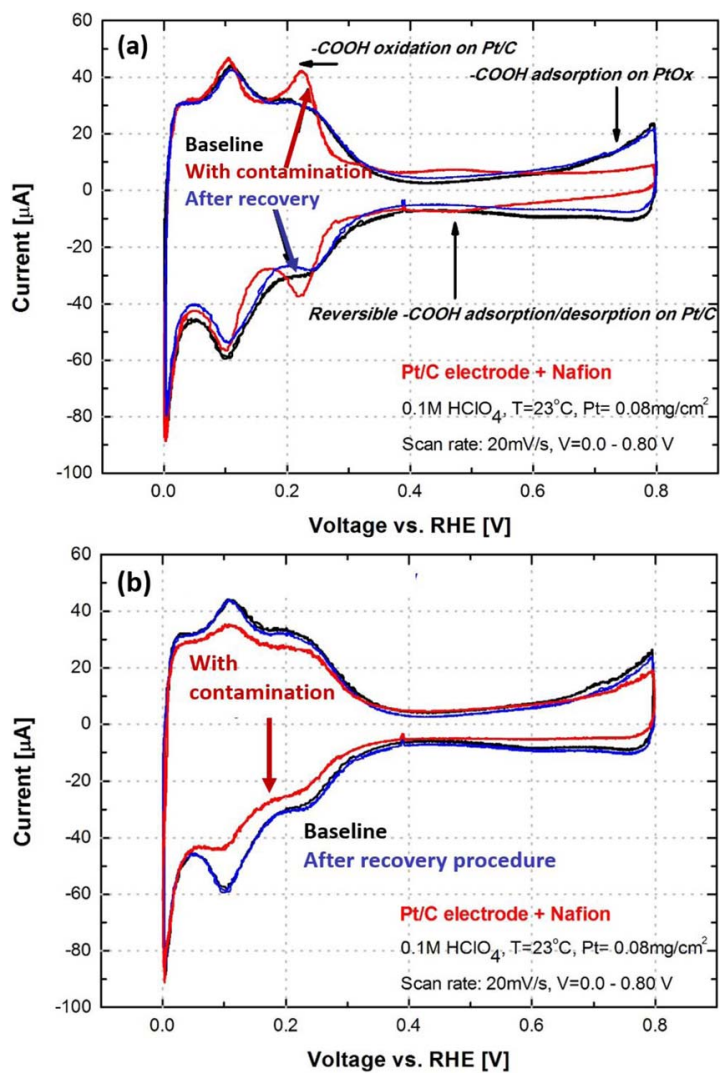

Figure 9. Partial CV scans of $\mathrm{Pt} / \mathrm{C}$ catalyst electrode in the presence of acetic acid $\left(\mathrm{CH}_{3} \mathrm{COOH}\right)$, ammonia $\left(\mathrm{NH}_{3}\right)$.

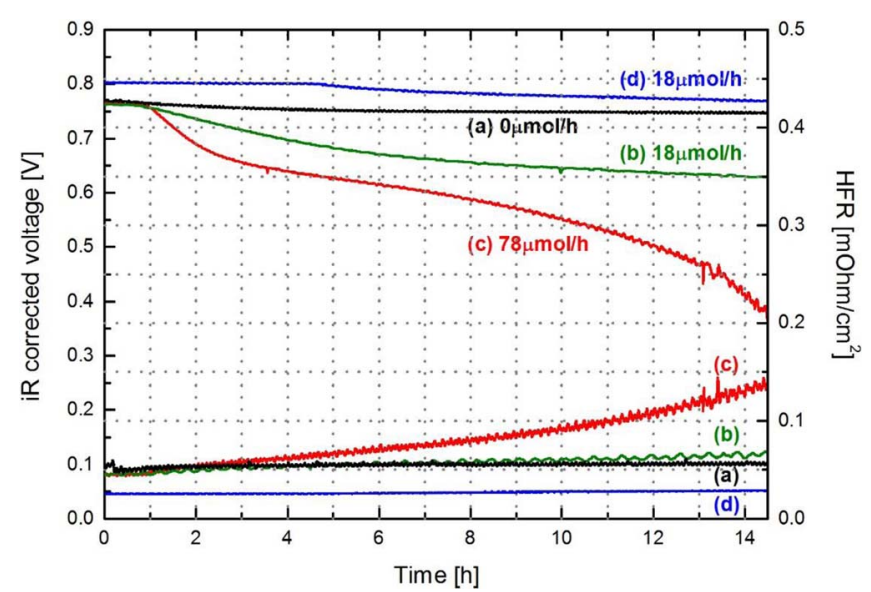

Figure 10. In-situ iR-corrected cell voltage and HFR responses at $80^{\circ} \mathrm{C}$ during $\varepsilon$-caprolactam infusion in a PEMFC: (a) no $\varepsilon$-caprolactam (b) $\varepsilon$-caprolactam feed rate $=18 \mu \mathrm{mol} / \mathrm{h}$ (c) $78 \mu \mathrm{mol} / \mathrm{h}$ (d) $18 \mu \mathrm{mol} / \mathrm{h}$ at $50^{\circ} \mathrm{C}$.

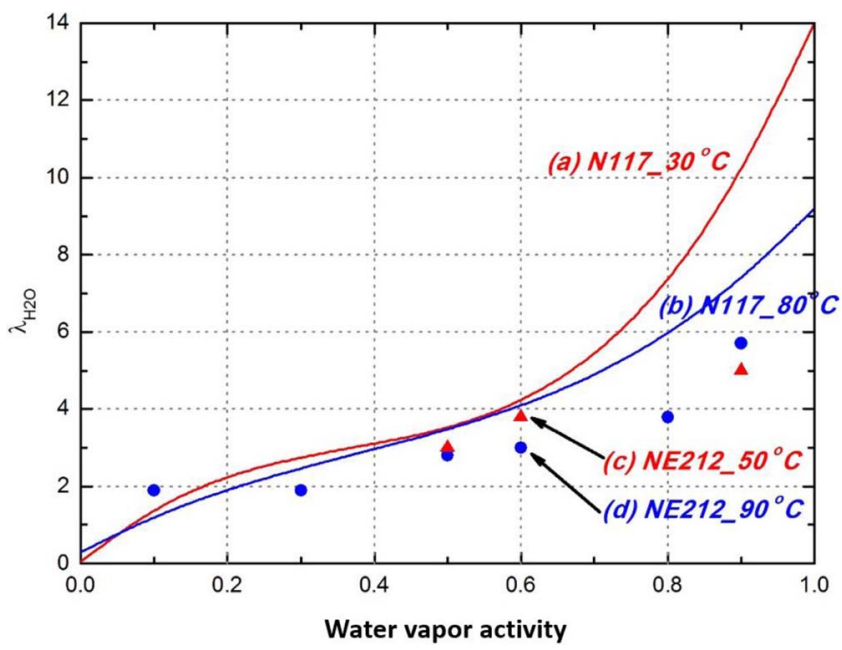

Figure 11. Water uptake plots for Nafion membranes at various temperatures and humidity (a) $\mathrm{N} 117$ at $30^{\circ} \mathrm{C}$ (b) $\mathrm{N} 117$ at $80^{\circ} \mathrm{C}$ (c) $\mathrm{NRE} 212$ at $50^{\circ} \mathrm{C}$ (d) $\mathrm{NRE} 212$ at $90^{\circ} \mathrm{C}$.

and $27 \%$ (line d) reductions in the ECSA, respectively, at $80^{\circ} \mathrm{C}$. The ECSA loss measured in situ is more comparable to the CV results measured ex situ at $\mathrm{pH} 2$ rather than those measured at $\mathrm{pH} 1$ (see $0.04 \mathrm{mM}$ and $0.2 \mathrm{mM}$ in Table IV). This comparison between ex situ and in situ CVs suggests that carboxylate anion $\left(-\mathrm{COO}^{-}\right)$may be the main chemical structure of the amino $\varepsilon$-caproic acid rather than the carboxylic acid (-COOH) in PEMFCs.

\section{Conclusions}

The effects of $\varepsilon$-caprolactam on PEMFCs were investigated to understand the contamination mechanisms. The membrane isotherms indicated a higher affinity of $\varepsilon$-caprolactam toward the PEM at $90^{\circ} \mathrm{C}$, but a lower affinity at ambient temperature. Greater membrane conductivity loss was also observed at higher temperatures. A possible explanation of this temperature effect is the endothermic ring-opening reaction of the amide bond (-NHCO-) of the cyclic $\varepsilon$-caprolactam. UV-vis and ATR-IR analyses supported the presence of $\varepsilon$-caprolactam in its open-ring structure in the PEM. The ECSA and kinetic current for the ORR of the Pt/C catalyst were also investigated and were observed to decrease upon contamination by the $\varepsilon$-caprolactam. By comparison of the CVs of ammonia and acetic acid, we confirmed the adsorption of carboxylic acid $(-\mathrm{COOH})$ or carboxylate anion $\left(-\mathrm{COO}^{-}\right)$onto the surface of the $\mathrm{Pt}$ 
catalyst. Additionally, their effects on the $\mathrm{Pt} / \mathrm{C}$ electrode were determined to be more severe at $\mathrm{pH} 2$ than at $\mathrm{pH} 1$. Finally, a comparison of in situ voltage losses at $80^{\circ} \mathrm{C}$ and $50^{\circ} \mathrm{C}$ also revealed temperature effects, especially in the PEM, as a result of the dramatic increase in the HFR. The voltage response for the $\varepsilon$-caprolactam infusion exhibited a linear, continuous decay, indicating that the ion-exchange mechanism was occurring as opposed to the absorption phenomenon.

\section{Acknowledgments}

The authors gratefully acknowledge the support for this work by the DOE EERE Fuel Cell Technologies Office (DE-AC3608GO28308) under a subcontract from NREL (ZGB-0-99180-1) to the University of South Carolina.

\section{Appendix A}

The total amount of ammonia feeding in RDE system can be calculated as assumed by ideal gas law. For example, total moles of feeding ammonium gas (997ppm) with 60 cc/min during $10 \mathrm{~min}$ at standard condition could be calculated as following.

$$
P V=n R T
$$

$$
V=\frac{n R T}{P}=\frac{1 \mathrm{~mol} \times 0.082 \mathrm{~atm} \cdot \mathrm{L} / \mathrm{K} \cdot \mathrm{mol} \times(273.15+23) \mathrm{K}}{1 \mathrm{~atm}}=24.3 \mathrm{~L}
$$

The volume of 1 mole of ammonia gas was calculated with assumption of ideal gas law so that we could find total amount of fed ammonia gas by multiple of the rate of ammonia gas and flow rates of ammonia gas.

$$
\begin{gathered}
1 \text { mole ideal gas }=\frac{1}{24.3} \text { moles } / L \\
997 \mathrm{ppm}=\frac{997}{10^{6}} \times \frac{1}{24.3} \times 10^{6}=41.0 \text { moles } / L \\
41.0 \text { moles } / L \times 60 \mathrm{cc} / \mathrm{min} \times 10 \mathrm{~min}=49.0 \text { moles }
\end{gathered}
$$

\section{Appendix B}

For in-situ concentration of $\varepsilon$-caprolactam at the channel could be estimated as follows:

$$
\begin{gathered}
C_{\varepsilon \text {-caprolactam }}=\frac{n_{\varepsilon-\text { caprolactam }}}{\dot{v}_{T}} \\
\dot{v}_{T}=\frac{n_{T} R T}{P} \\
n_{T}=n_{\text {air }}+n_{\text {water }}+n_{\varepsilon-\text { caprolactam }}
\end{gathered}
$$

where $\mathrm{P}=$ pressure $[\mathrm{kPa}], \mathrm{T}=$ temperature $[\mathrm{K}], \mathrm{V}=$ volume $[\mathrm{L}], n=$ molar flow rate $[\mathrm{mol} / \mathrm{s}], v=$ volumetric flow rate $[\mathrm{L} / \mathrm{s}], \mathrm{R}=$ gas constant $[\mathrm{LkPa} / \mathrm{K} \mathrm{mol}], \mathrm{C}=$ concentration $[\mathrm{M}]$, subscript $\mathrm{T}_{\mathrm{T}}=$ total

\section{References}

1. R. Borup, J. Meyers, B. Pivovar, Y. Kim, R. Mukundan, N. Garland, D. Myers M. Wilson, F. Garzon, D. Wood, P. Zelenay, K. More, K. Stroh, T. Zawodzinski, J. Boncella, J. E. McGrath, M. Inaba, K. Miyatake, M. Hori, K. Ota, Z. Ogumi, S. Miyata, A. Nishikata, Z. Siroma, Y. Uchimoto, K. Yasuda, K. Kimijima, and N. Iwashita, Chem. Rev. 107, 3904 (2007).

2. H. J. Soto, W-k. Lee, J. W. Van Zee, and M. Murthy, Electrochem. Solid-State Lett. 6, A133 (2003)

3. R. M. Jung, H-S. Cho, S. Park, and J. W. Van Zee, J. Power Sources 275, 14 (2015)

4. F. A. Uribe and T. A. Zawodzinski Jr., "The effects of fuel impurities on PEM Fue Cell performance," Paper \#339, presented at the $200^{\text {th }}$ ECS Meeting in San Francisco, CA, Sep. 2, 2001.

5. J. St-Pierre, in Polymer electrolyte fuel cell durability F. Buchi, M. Inaba, and T. J. Schmidt, Editors, p. 289, Springer, New York (2009).

6. H. Li, J. Gazzarri, K. Tsay, S. Wu, H. Wang, J. Zhang, S. Wessel, R. Abouatallah, N. Joos, and J. Schrooten, Electrochim. Acta 55, 5823 (2010).

7. M. Sulek, J. Adams, S. Kaberline, M. Ricketts, and J. R. Waldecker, J. Power Source 196, 8967 (2011)

8. Y. Garsany, O. A. Baturina, and K. E. Swider-Lyonsa, J. Electrochem. Soc. 154, B670 (2007)
9. R. Mohtadi, W-k. Lee, and J. W. Van Zee, J. Power Sources 138, 216 (2004).

10. T. Gu, W-k. Lee, and J. W. Van Zee, Appl. Catal. B-Environ. 56, 43 (2005).

11. R. Mohtadi, W-k. Lee, S. Cowan, J. W. Van Zee, and M. Murthy, Electrochem. Solid-State Lett. 6, A272 (2003).

12. J. Z. Tan, Y. J. Chao, J. W. Van Zee, and W-k. Lee, Mater. Sci. and Eng. A 445, 669 (2007).

13. T. Okada, J. Electroanal. Chem. 465, 18 (1999).

14. K. Hongsirikarn and J. G. Goodwin Jr., S. Greenway and S. Creager, J. Power Sources 195, 7213 (2010).

15. M. J. Kelly, G. Fafilek, J. O. Besenhard, H. Kronberger, and G. E. Nauer, J. Power Sources 145, 249 (2005).

16. M. J. Kelly, B. Egger, G. Fafilek, J. O. Besenhard, H. Kronberger, and G. E. Nauer, Solid State Ionics 176, 2111 (2005).

17. M. Ohashi, Ph.D. dissertation, Department of Chemical Engineering, University of South Carolina 2009

18. H. Li, J. Gazzarri, K. Tsay, S. Wu, H. Wang, J. Zhang, S. Wessel, R. Abouatallah, N. Joos, and J. Schrooten, Electrochim. Acta 55, 5823 (2010).

19. T. Okada, J. Dale, Y. Ayato, O. A. Asbjørnsen, M. Yuasa, and I. Sekine, Langmuir 15, 8490 (1999).

20. T. Okada, H. Satou, and M. Yuasa, Langmuir 19, 2325 (2003).

21. T. Okada, Y. Ayato, H. Satou, M. Yuasa, and I. Sekine, J. Phys. Chem. B 105, 6980 (2001).

22. T. Okada, Y. Ayato, J. Dale, M. Yuasa, I. Sekine, and O. A. Asbjørnsen, Phys. Chem Chem. Phys. 2, 3255 (2000).

23. T. Okada, N. Arimura, H. Satou, M. Yuasa, and T. Kikuchi, Electrochim. Acta 50, 3569 (2005).

24. T. Okada, S. Moller-Holst, O. Gorseth, and S. Kjelstrup, J. Electroanal. Chem. 442, 137 (1998).

25. K. Honsirikarn, X. Mo, and J. G. Goodwin Jr., J. Power Sources 195, 3416 (2010).

26. M. Jung, Ph. D. dissertation, Department of Chemical Engineering, University of South Carolina, 2010.

27. R. Halseid, P. J. S. Vie, and R. Tunold, J. Electrochem. Soc. 151, A381 (2004)

28. T. A. Zawodzinski Jr., C Derouin, S. Radzinski, R. J. Sherman, V. T. Smith, T. E. Springer, and S. Gottesfeld, J. Electrochem. Soc. 140, 1041 (1993).

29. F. A. Uribe, S. Gottesfeld, and T. A. Zaodzinski Jr., J. Electrochem. Soc. 149, A293 (2002).

30. X. Zhang, U. Pasaogullari, and T. Molter, Int. J. Hydrogen Energy 34, 9188 (2009).

31. H-S. Cho, M. Jung, J. Navarro, M. Ohashi, and J. W. Van Zee, ECS Trans., 33(1), 1627 (2010)

32. H. Wang, C. S. Macomber, J. Christ, G. Bender, B. Pivovar, and H. N. Dinh, Elec trocatalysis $\mathbf{5}, 62(2014)$

33. P. T. Yu, E. A. Bonn, and B. Lakshmanan, ECS Trans., 58(1), 665 (2013).

34. J. M. Christ, K. C. Neyelin, H. Wang, R. Richards, and H. N. Dinh, ECS Trans., 50(2) 691, (2013)

35. H-S. Cho, Ph.D. dissertation, Department of chemical engineering, University of South Carolina (2013)

36. http://www.hydrogen.energy.gov/pdfs/2011 budget_request briefing.pdf.

37. http://www.hydrogen.energy.gov/pdfs/progress14/v_f_1_dinh_2014.pdf.

38. K. O'Leary and B. Lakshaman, "Methods for Screening Balance of Plant (BOP) Materials for Fuel Cell Contamination," Paper \#1036, presented at the $220^{\text {th }}$ ECS Meeting \& Electrochemical Energy Summit in Boston, MA, Oct. 13, 2011.

39. C. Macomber, H. Wang, K. O'Neill, S. Coombs, G. Bender, B. Pivovar, and H. N. Dinh, ECS Trans. 33(1), 1637 (2010).

40. C. S. Macomber, J. Christ, H. Wang, B. S. Pivovar, and H. N. Dinh, ECS Trans. 50(2), 603, (2013)

41. H-S. Cho, M. Ohashi, and J. W. Van Zee, ECS Trans., 41(1), 1487 (2011).

42. B. C. Challis and J. Challis, The Chemistry of Amides J. Zabicky, Editor, p.748 Interscience, New York, (1970)

43. C. J. O'Connor, Q. Rev. Chem. Soc. 24, 553 (1970).

44. H. K. Reimschuessel, in Ring-Opening Polymerization, T. Saegusa and E. Goethals, Editors, 59, p. 233, ACS symposium series, American chemical society, Washington, DC (1977).

45. M. Liler, in Reaction Mechanisms in Sulfuric Acid, p.189, Academic Press, London (1971).

46. G. B. Deacon, F. Huber, and R. J. Phillips, Inorg. Chim. Acta 104, 41 (1985).

47. T. Xue, R. B. Longwell, and K. Osseo-Asare, J. Mem. Sci. 58, 175 (1991).

48. D. C. Harris, Quantitative Chemical Analysis, W. H. Freeman and Company, New York (2003).

49. Friedrich Helfferich, Ion Exchange, p 157, Dover publication Inc, New York (1995)

50. R. Buzzoni, S. Bordiga, G. Ricchiardi, G. Spoto, and A. Zecchina, J. Phys. Chem. 99, 11937 (1995).

51. A. Gruger, A. Regis, T. Schmatko, and P. Colomban, Vib. Spectrosc. 26, 215 (2001)

52. K. A. Mauritz and R. B. Moore, Chemical reviews 104, 4535 (2004).

53. Y. Wang, Y. Kawano, S. R. Aubuchon, and R. A. Palmer, Macromolecuels 36, 1138 (2003).

54. G. Socrates, Infrared and Raman Characteristic Group Frequencies: Tables and Charts, 3 rd edition, John Wiley \& Sons, Ltd., (2004).

55. W. Paik, S. Han, W. Shin, and Y. Kim, Langmuir 19, 4211 (2003).

56. T. E. Springer, T. A. Zawodzinski, and S. Gottesfeld, J. Electrochem. Soc. 138, 2334 (1991).

57. J. T. Hinatsu, M. Mizuhata, and H. Takenaka, J. Electrochem. Soc. 141, 1493 (1994). 